\title{
Patterning aspects of small solar power development in Uzbekistan
}

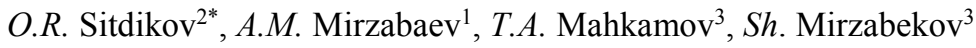 \\ 1 "MIR SOLAR" LLC, Uzbekistan, Tashkent \\ ${ }^{2}$ International Institute of Solar Energy (IISE), Uzbekistan \\ ${ }^{3}$ Tashkent State Technical University, Uzbekistan
}

\begin{abstract}
The article describes the experience of "Mir Solar" LLC (Uzbekistan) in the use of patterning for the development and formation of small solar energy. The paper describes the patterning of the problem field of solar energy, which leads to effective practical solutions in the energy supply of rural and remote consumers of electric energy. The use of patterns shows that they contribute to the solution of many problems arising from the use of photovoltaic installations (PV), providing reliability and efficiency of power supply. Examples of effective implementation using patterning methods are given.
\end{abstract}

\section{Introduction}

Around the world, energy based on renewable sources is developing rapidly due to many reasons: the limitations of traditional fuel resources, environmental requirements, consumer demand, etc. [1]. The factors determining the development of renewable energy technologies are: long-term forecasting of electricity consumption; change in the structure of energy consumption, changing in developed countries towards decentralized consumption; low-carbon fuel energy, which is based on the rejection of coal, oil, gas and the transition to new alternative sources; automation and intellectualization of accounting, monitoring and management systems in the energy sector; environmental pollution and others.

\section{General information about patterning}

This term is derived from the English word "pattern", which translates as "pattern", "example", "form", "structure". Pattern (eng. pattern-pattern, pattern, system) is a borrowed word that is used as a term in many modern technologies [2].

The term pattern refers to a repeated pattern or a pattern that is predictable is reproduced. When we talk about patterns, we mean their presence or absence in the relevant field of activity. They often look the same, but do not always copy each other and can be diverse. [3] Currently, there are many varieties of patterns, which in our case can be divided into two groups: the formation of continuation and reversal of the trend. For small energy, the continuation and reversal models indicate the further development of the trend and are signals to open new positions (patterns) in accordance with current trends in technical, technological, regulatory, organizational and other areas.

\section{Methodological aspects of patterning in small power engineering}

Trends in the development of small-scale energy and facts suggest that there will be a further transition to a combined system of centralized and decentralized energy supply, in which small, including solar energy, will occupy an important place in our Republic [4-6].

The analysis shows that the processes of its development and functioning require appropriate components of support: technical and technological, financial and innovative, regulatory, organizational, educational, scientific, training of relevant specialists, etc.at the same time, as experience shows, it is necessary to adhere to and use patterning as one of the effective mechanisms to ensure the efficiency of energy systems, including small.

Small-scale solar energy technology patterns need to be introduced in sectors and clusters such as the private sector; micro-grid formations; local generation; energy storage; energy supply to agriculture and remote consumers.

The "Mir Solar" LLC is active in the field of solar energy of the Republic of Uzbekistan more than 15 years, and use patterns in this area helped to design and implement effective technical and technological solutions allowing to combine the best properties of the most common types of solar technologies and installations, which is important to ensure remote from large electricity consumers, such as the water system of livestock and crop production, communications, meteorological system etc. We are talking about the use

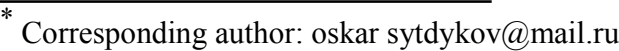


of those types of equipment that are produced on a large scale, have low market prices and are easy to operate.

The innovative role of the introduction of patterning techniques in the formation of small energy is that it allows you to select the best properties: reliability, efficiency, low prices, ease of installation and maintenance, durability, payback in an acceptable time.

The development of small-scale energy requires comprehensive state support, including the creation of an appropriate system of regulatory support, standardization, the introduction of various preferences, benefits to producers and consumers, "green" tariffs, etc.the use of solar photovoltaic plants (FES) together with wind, biogas, small hydropower plants, geothermal, hydrogen and other installations, as well as energy storage facilities is understood as a complex. It is necessary to use the experience of other countries where patterning is widely used. For example, Pattern Energy Group (PEGI) is an independent international renewable energy company, successfully engaged in solar and wind generation in a number of countries, in particular, in the United States, Canada, Chile and Japan. The company operates wind and solar power plants with a total capacity of 2942 MW [7-8].

On the basis of patterning specialists of "MIR SOLAR" LLC developed effective circuit solutions of FES for power supply of pumps of water lifting of agriculture, remote stations of cellular communication, rural medical posts, etc., providing reliability and continuity of their power supply.

Long-term operation more than 1500 objects assembled, "MIR SOLAR" LLC is confirmed by longterm use ( 5 to 15 years or more), and return - the costs of purchased equipment and operation of FES within 812 years [4-6,9].

In all applied technologies and the used types of the equipment and actions "MIR SOLAR" LLC has the "know-how". The quantitative ratios used simultaneously on PMT panels of monokristalline and polikristalline silicon, the corners of their attitudes to the countries of the world (with oatom of the wind rose), horizon properties used and developed special controllers, cooling systems, inverters, choice of $\mathrm{AB}$ system, warranty service, etc. All this allows to provide long-term reliability and efficiency of the installed equipment, to expand the market of FES [9].

As a necessary pattern, several groups of students of the energy faculty of Tashkent state technical University annually undergo practical training at the MIR SOLAR LLC enterprise. This contributes to the development of small solar energy in the Republic, and the company allows it to determine the necessary graduates and provide them with qualified work.

\section{Example 1. Guaranteed energy supply of water supply systems}

The most successful solar technologies based on patterning are implemented in agriculture, in particular for guaranteed water supply of remote areas [10].
The main way to solve the problem of providing the needs of the population and agriculture with fresh water in remote arid and arid areas is the use of artesian wells. Therefore, the issue of guaranteed power supply of electric drives of such pumps is very relevant for the arid regions of the Republic of Uzbekistan, as well as the countries of Central Asia.

In modern practice, two main schemes of using photovoltaic panels (FEP) for water lifting are successfully operated - accumulator-free and with a battery (AB). Such schemes and the corresponding equipment were selected using the patterning described earlier, which allowed to identify the most suitable variants of equipment and schemes, taking into account their further operation in specific local conditions.

In this case, conventional types of equipment are used, including typical inverters (table 1.).

Table 1. Main parameters of widely used pump inverters

\begin{tabular}{|c|c|c|c|c|c|}
\hline Pump & \multirow{2}{*}{$\begin{array}{c}\text { rated } \\
\text { inverter } \\
\text { type }\end{array}$} & $\mathbf{v} \begin{array}{c}\text { voltage, } \\
\text { V }\end{array}$ & \multicolumn{2}{|c|}{$\begin{array}{c}\text { kW rated } \\
\text { power }\end{array}$} & \multicolumn{2}{|c|}{$\begin{array}{c}\text { kW } \\
\text { recommended }\end{array}$} \\
\cline { 3 - 6 } & $\mathrm{P}_{\min }$ & $\mathrm{P}_{\max }$ & $\mathrm{U}_{\min }$ & $\mathrm{U}_{\max }$ \\
\hline $\begin{array}{c}\text { Single } \\
\text { phase }\end{array}$ & 220 & 0,5 & 5 & 290 & 500 \\
\hline $\begin{array}{c}\text { Three } \\
\text { phase }\end{array}$ & 380 & 3,0 & 75 & 500 & 900 \\
\hline
\end{tabular}

1. Accumulator-free scheme of water lifting using photovoltaic panels-FEP.

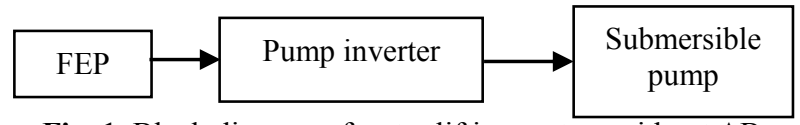

Fig. 1. Block diagram of water lifting system without $A B$

The main element of this system (Fig. 1.) is an inverter to drive pumps with asynchronous motors. The advantage of such a scheme is the relative simplicity, cheapness and durability of the installation, and the disadvantage is the possibility of using it only for water supply needs, and the continuity of water supply is provided by the accumulation of water.

2. The accumulator scheme of ensuring water lifting with use of FEP (Fig. 2.).

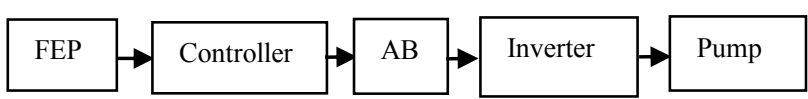

Fig. 2. Block diagram of the battery system of water lifting

This scheme is an example of using a classic GRIDOFF scheme (without connection to a common network), the main advantage of which is the ability to operate around the clock and feed other consumers, and the main drawback is the relative high cost due to the cost of installing $\mathrm{AB}$ and the need for periodic replacement.

The need for irrigation water is seasonal, so often FES remain unloaded. With the current shortage of electricity in remote rural areas, the use of these FES at full capacity becomes relevant.

Taking into account the advantages and disadvantages of the main power supply schemes of water lifting systems, scientists of Tashstu, MISE and specialists of "MIR SOLAR" based on the experience of 
developing photovoltaic systems, offer a more flexible connection scheme that guarantees the use of a minimum number of $\mathrm{AB}$. The structure of such a scheme is shown in Fig. 3.

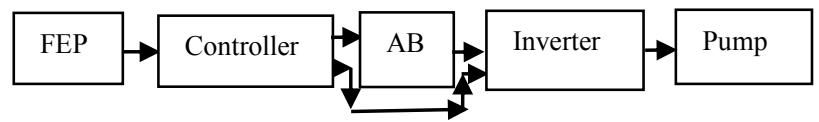

Fig. 3. Fes block diagram developed by MIR SOLAR LLC for remote power supply systems

The main advantage of the proposed scheme is the possibility of using a minimum number of expensive $A B$ at high values of total power and, accordingly, the connected pump and / or other consumers.

The controller provides for disabling the charging current stabilization function, allowing it to be used as a normal controller. Thus, if necessary, $\mathrm{AB}$ is used as a stabilizing factor: in cloudy weather and to power household equipment in the dark.

It can be noted that such systems are able to fully provide water to the needs of livestock in remote and arid regions of our Republic, as well as other water users of agriculture.

To date, the Republic is very successfully operated several dozen solar systems of deep water lifting of different capacities under this scheme, mounted LLC "MIR SOLAR", and the need for them is expanding day by day (table 2 ).

Table 2. Dislocation of some water lifting stations equipped with equipment of "Mir Solar" LLC»

\begin{tabular}{|l|l|l|l|l|}
\hline Location & $\begin{array}{l}\text { kW } \\
\text { FES } \\
\text { Power }\end{array}$ & $\begin{array}{l}\text { kW } \\
\text { pump } \\
\text { Power }\end{array}$ & $\begin{array}{l}\text { Flow, } \\
\text { not less } \\
\text { than } \\
\text { (m3 / h) }\end{array}$ & $\begin{array}{l}\text { lifting } \\
\text { Height, } \\
\mathbf{m}\end{array}$ \\
\hline Kushrabat & 8 & 5,5 & 25 & 50 \\
\hline Bektemir & 8 & 5,$5 ;$ & 35 & 20 \\
& & 5,5 & & \\
\hline TIIMSH & 9,2 & 7,5 & 40 & 40 \\
\hline TIIMSH & 9,2 & 7,5 & 40 & 35 \\
\hline TIIMSH & 9,2 & 7,5 & 40 & 35 \\
\hline Fergana & 9,2 & 7,5 & 40 & 35 \\
\hline Samarkand & 13,5 & 9,$2 ;$ & 60 & 40 \\
\hline Andijan & 13,5 & 7,5 & 15 & 80 \\
\hline Samarkand & 13,5 & 9,$2 ;$ & 40 & 40 \\
\hline Agricultural i-t & 18,5 & 13 & 110 & 30 \\
\hline Agricultural i-t & 18,5 & 13 & 110 & 30 \\
\hline Samarkand & 20 & 15 & 50 & 50 \\
\hline Jizzakh & 37 & $30 ; 26$ & 80 & 80 \\
\hline
\end{tabular}

\section{Example 2. Photovoltaic plant for reliable power supply of base stations of cellular companies}

Engineering and technical staff of one of the world's leading mobile operators working in Uzbekistan, together with scientists of Tashkent state technical University and specialists of "MIR SOLAR", studied the possibilities of application, advantages and disadvantages of different approaches to ensure uninterrupted power supply of base stations (BS) of cellular communication systems operating from FEU. Various options of backup power supply sources were considered:

- laying a backup power line from the transformer substation;

- increase the number of batteries BS;

- installation of wind turbines;

- use of diesel generators;

- installation of FES.

The first option disappeared immediately because of the high cost and impossibility of laying power lines over relatively long distances. And all nearby substations, as a rule, are disconnected at the same time.

The second option is rejected because of the high cost of the $\mathrm{AB}$ and powerful chargers and, most importantly, because of the inexpediency. In winter, $A B$ simply do not have time to fully charge.

The third option was rejected due to the lack of stable wind at low altitudes and the need for maintenance of rotating parts. Recall that the optimal wind speed for low-power wind turbines is $12-15 \mathrm{~m} / \mathrm{s}$.

The fourth option was rejected because of the relative high cost of high-quality diesel generators, their limited service life compared to FES and, most importantly, the need for continuous maintenance and rising prices for fuel and lubricants.

On the basis of the calculations, their analysis and the experience of patterning, appropriate decisions were made, including the use of FES as both the main and backup power source of the BS, when using $\mathrm{AB}$.

In addition, calculations and operating experience of such FES have shown that with a three-fold difference in solar radiation in summer and winter [2], it is most effective to mount photovoltaic panels (PV panels) at a certain angle, which allows to ensure the maximum power of the PV in the winter months and does not contribute to the formation of snow cover.

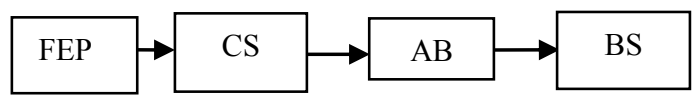

Fig.4. Block diagram of BS power supply

A distinctive feature of the proposed version of the FES $5 \mathrm{~kW}$ is the simultaneous use of both types of widespread solar panels, i.e. part of the power is generated on panels made of monocrystalline silicon, and the other part - on panels made of polycrystalline silicon; in the presence of a specially designed controller (CS).

The joint combination and use of a certain ratio of monocrystalline and polycrystalline solar panels gives the greatest reliability and efficiency when taking into account the peculiarities of operation of a particular station, including-economic, climatic, insolation, as well as load schedules BS and others. In table 3 the parameters of such a FES for the power supply of one of the cellular communication stations in Uzbekistan are given. 
Table 3. Main parameters of FES produced by MIR SOLAR

$$
\text { LLC» }
$$

\begin{tabular}{|c|c|c|c|c|c|c|c|}
\hline $\begin{array}{c}\text { Type of solar } \\
\text { element (SE) }\end{array}$ & $\begin{array}{c}\text { number of } \\
\text { FEP SE }\end{array}$ & $\begin{array}{c}\text { Maximum } \\
\text { power W }\end{array}$ & $\begin{array}{c}\text { Voltage } \\
\text { with max is } \\
\text { powerful,V }\end{array}$ & $\begin{array}{c}\text { In Current } \\
\text { at max }\end{array}$ & $\begin{array}{c}\text { Voltage } \\
\mathbf{x x , ~ V}\end{array}$ & $\begin{array}{c}\text { In the } \\
\text { short- } \\
\text { circuit } \\
\text { Current }\end{array}$ & $\begin{array}{c}\text { And the } \\
\text { Efficiency of } \\
\text { the SE, \% }\end{array}$ \\
\hline $\begin{array}{c}\text { Monocrystalline } \\
\text { silicon }\end{array}$ & 72 & 200 & 37,8 & 5,39 & 45,25 & 5,92 & 18,5 \\
\hline $\begin{array}{c}\text { Polycrystalline } \\
\text { silicon }\end{array}$ & 60 & 265 & 30,5 & 8,17 & 36,9 & 9,15 & 16,5 \\
\hline
\end{tabular}

In this case, monocrystalline PECs are installed at a certain angle in the south direction, and polycrystalline PECs in the south-east direction. This arrangement of the solar cells provides fast charging of discharged batteries during the night and the most complete charge in the evening.

The most important component of the FES is the KS - the charge-discharge controller AB, specially designed and manufactured by the specialists of the manufacturing enterprise LLC MIR SOLAR, taking into account the peculiarities of the operation of the BS (patent UZ.SMT.01.002.1806349).

The developed CS allows controlling the total charge current, i.e. the power of the photovoltaic panels is regulated depending on the current of the charger built into the BS. This factor significantly increases the battery life, because prevents the possibility of "boiling" of batteries. The SC allows, as necessary, to gradually turn on and off individual BS functional units, depending on the charge level of the battery, which maximizes the possibility of providing priority telecommunication services.

$\mathrm{KS}$ is designed taking into account local climatic conditions. The installed radiators of a special design allow you to abandon the vulnerable forced ventilation system and increase the life of the unit. KS allows you to adjust the value of the charge current and the shutdown threshold of the battery at the request of the customer. The most vulnerable component of FES is AB. The specialists of MIR SOLAR LLC did a great job of choosing the type and manufacturer of the battery, their optimal number and connection schemes. Based on the criterion of "price-quality", helium batteries of the PW 100-12 type were selected (table 4) [11].

Table 4. Parameters of $\mathrm{AB}$

\begin{tabular}{|c|c|c|c|c|c|c|c|}
\hline \multirow[t]{2}{*}{$\begin{array}{c}\text { Bra } \\
\text { nd }\end{array}$} & \multirow[t]{2}{*}{$\begin{array}{l}\text { Ty } \\
\text { pe }\end{array}$} & \multirow[t]{2}{*}{$\begin{array}{l}\text { Weig } \\
\text { ht kg }\end{array}$} & \multirow{2}{*}{$\begin{array}{c}\text { Capaci } \\
\text { ty, } \\
\text { A* } \\
\text { hour }\end{array}$} & \multirow[t]{2}{*}{$\begin{array}{l}\text { Volta } \\
\text { ge, V }\end{array}$} & \multicolumn{3}{|c|}{$\begin{array}{c}\text { in number of } \\
\text { charge- } \\
\text { discharge cycles }\end{array}$} \\
\hline & & & & & $\begin{array}{c}100 \\
\%\end{array}$ & $\begin{array}{l}50 \\
\%\end{array}$ & $\begin{array}{l}30 \\
\%\end{array}$ \\
\hline $\begin{array}{c}\text { PW } \\
100- \\
12\end{array}$ & $\begin{array}{c}\text { GE } \\
\text { L }\end{array}$ & 30,5 & 100 & 12 & 600 & $\begin{array}{c}100 \\
0\end{array}$ & $\begin{array}{c}140 \\
0\end{array}$ \\
\hline
\end{tabular}

The total capacity of AB $3200 \mathrm{~A}^{*} \mathrm{~h}$ (32 pieces of 100 $\left.A^{*} h\right)$ selected taking into account the BS power consumption allows to fulfill the manufacturer's requirement of inadmissibility of discharge below $50 \%$. It should be noted that the scientific and applied approach to solving the problem and the high qualification of specialists of "MIR SOLAR" LLC convinced the leadership of the largest mobile operator of Uzbekistan to choose the proposed FES as a reliable source of power supply to the BS. To date, $280 \mathrm{BS}$ Uzbekistan successfully operated FES production of "MIR SOLAR" LLC.

\section{Conclusion}

Patterning has fully justified itself in the selection, installation and operation of solar installations with a capacity of $5-50 \mathrm{~kW}$ to ensure reliable and uninterrupted power supply to rural and remote facilities. This is confirmed by the experience of operation and monitoring of more than 1,500 facilities in Uzbekistan, equipped with FEU LLC "Mir Solar".

\section{References}

1. Allaev K.R., etc., The power sector of Uzbekistan and prospects of its development. - T.: Fan va texnologiyalar. 2016, -296 p.

2. https://xn----8sbfgf1bdjhf5a1j.xn--p1ai/1339-patternchto-znachit.html.

3. http://www.02s.ru/readarticleaf77.htm.

4. Mirzabaev A.M., Sytdykov O.R., Mirzabekov Sh.M., Dungbaev Sh. I., Nurimbetov S.P. Photovoltaic installation for guaranteed power supply of a remote object / in SB. "Modern problems of semiconductor physics and development of renewable energy sources", -Andijan. On April 20-21, 2018

5. Mirzabaev A.M., Makhkamov T.A. DEVELOPMENT DYNAMICS OF OOO "MIR SOLAR"./Applined Solar Energy, 2013, Vol.49 No4, Allerton Press, Inc (United States), pp 272-274.

6. Mirzabaev A.M., Kanonerov V.P., Makhkamov T.A., Sytdykov O.R., Mirzabekov Sh. M. Photovoltaic installation for power supply of base stations of cellular companies. //Solar technology. 2018. No. 1. Pp. 47-51.

7. http://www.patternenergy.com

8.https://ru.glosbe.com/en/ru/energy $\% 20$ utilization $\% 20$ p attern

9. Mirzabaev A.M., Sitdikov O.R., Mahkamov T.A. Mirzabekov, Sh.M. Integration of photovoltaic systems for water lifting in the electrical network. // Problems of energy and resource saving. 2018. No. 3-4. Pp. 313-317. 10. Alternative energy sources: opportunities for use in Uzbekistan. /Analytical report 2011/03. Economic research.

11. https://bigteh.ru/category/akb-gel-serija/. 